\title{
EJEM \\ Econ.J.Emerg.Mark.

\section{Government fiscal spending and crowd-out of private investment: An empirical evidence for India}

\author{
Shiv Shankar ${ }^{1 *}$, Pushpa Trivedi ${ }^{2}$ \\ ${ }^{1}$ Department of Statistics and Information Management, Reserve Bank of India, Mumbai, India \\ ${ }^{2}$ Department of Humanities and Social Sciences, Indian Institute of Technology Bombay, Mumbai, India \\ * Corresponding author: shivshankars@rbi.org.in
}

\begin{tabular}{l} 
Article Info \\
\hline Article bistory: \\
Received : 31 January 2021 \\
Accepted : 8 March 2021 \\
Published : 1 April 2021 \\
\hline JEL Classification Code: \\
C32, E22, H60 \\
Author's email: \\
shivshankars@rbi.org.in \\
trivedi@hss.iitb.ac.in \\
DOI: 10.20885/ejem.vol13.iss1.art8
\end{tabular}

DOI: $10.20885 /$ ejem.vol13.iss1.art8

\begin{abstract}
Purpose - The paper evaluates the crowding-in or crowding-out relationship between public and private investment in India, controlling fiscal and monetary variables.

Methods - In a flexible accelerator theoretical framework, the paper estimates long and short-run investment dynamics, employing Autoregressive Distributed Lag (ARDL) cointegration approach. We use a back series of national account statistics that incorporates enhanced coverage of the organized corporate sector.
\end{abstract}

Findings - Our results suggest investment complementarity between the public and private sector at an aggregate and sectoral level over the period 1981-2019. Barring short-run crowding-out in construction and financial services at industry level, public investment stimulates private counterparts, both in the long and short-run. However, fiscal deficit, inflation expectation, and sovereign vulnerability influence private investment adversely. Moreover, the long-run crowding-out bearing of fiscal imbalance is quantitatively higher when the public sector invests in mining and manufacturing and insignificant with infrastructure.

Implication - Sizable infrastructure investment as a proportion of government finances would moderate the adverse impact of the deficit on private investment. Further, quality fiscal adjustments and containing inflation would enhance private investment activities.

Originality - Besides aggregate and sectoral levels, the study also evaluates the impact of industry-level public investment on private capital expenditure. This paper also incorporates derived variables in the regression framework using statistical filters and the principal component technique.

Keywords - Public investment, private investment, crowding-out, statistical filter.

\section{Introduction}

Economic growth of an economy is contingent upon investments in physical capital, human capital and technological development by all its stakeholders. In this respect, crowding-out of private investment attracts attention time and again, more so with an expansionary fiscal action in developing countries. Broadly, crowding-out is expected when public investment utilises more resources that would be otherwise available to the private sector or if it produces marketable output that competes with the output produced by the private sector. The 'real or direct' crowd-out occurs 
when increase in public capital formation displaces private investment directly; whereas partial loss of private sector investment due to hardening of interest rates is referred as 'financial or indirect' crowd-out (Buiter, 1990). For developing economies, enhanced public investment also supports growth indirectly through positive sentiment building channel and helps productivity enhancement leading to healthier growth prospects (Afonso \& St. Aubyn, 2010). Though the country specific factors dominate while making investment decision by private corporates, public fixed capital formation in developing economies has virtuous complementary effect (Atukeren, 2010). On a similar line, considering 39 developed and developing economies, Ahmed and Miller (2000) conclude that government spending in transport and communication attracts private investment only in developing countries, while expenditure on social security and welfare scheme crowd-out investment for both developed and developing economies.

In country specific studies, government spending crowd-in private investment in Turkey, while budget deficits crowd it out (Şen, H., \& Kaya, 2014). Moreover, Wang (2005) argues that public expenditure on health and education in Canada compliments, while expenditure on infrastructure and social security schemes substitutes private investment due to active participation of private corporates in physical infrastructure sector than in human capital formation. The asymmetric substitutive and complimentary relationship have also been observed for the Brazilian and Chinese economy in short and long-run, respectively (Cruz \& Teixeira, 1999; Wu \& Zhang, 2009). However, for South Africa, government investment neither crowds-in nor crowds-out private investment, though government spending in social and infrastructure sectors may indirectly influence private investment through accelerator effect (Kollamparambil \& Nicolaou, 2011). In case of Pakistan, studies opinion that government's expenditure in defence, debt servicing and manufacturing sector decelerates private investment, while expenditure on infrastructure, health, education and agriculture attracts (Hussain, Muhammad, Akram, \& Lal, 2009; Saeed, Hyder, Ali, \& Ahmad, 2006). In Indian context, government's investment driven short-run substitutive impact for private sector is neutralised through output expectations in long run, thereby offsetting initial crowding-out effect (Dash, 2016; Mitra, 2006). Serven (1999) however, at sectoral level concludes that public infrastructure investment complements private investment in long-run, but crowds-out in short-run through credit rationing and hardening of interest rate. Contrary to this, using asymmetric VAR, Chakraborty (2007) opines investment complementarity conditional upon exchange rate and fiscal deficit between the two sectors. Moreover, underscoring importance of reforms, Bahal, Raissi, and Tulin (2018) argue for complimentary relationship only with restricted dataset, post 1980. Recently, estimation using non-linear ARDL also argues investment complementarity for India in long and short-run controlling foreign direct investment, expected output and interest rate (Akber, Gupta, \& Paltasingh, 2020).

The fiscal deficit influences adversely to private investment and poses a downside risk to growth. Many studies considering panel data suggest that deficit crowds out private investment marginally in developed countries (Mahmoudzadeh, Sadeghi, \& Sadeghi, 2017) and significantly in oil-dependent economies primarily through credit channel than interest rate channel (Anyanwu, Gan, \& Hu, 2018). In a similar line, fiscal deficit significantly crowds-out private investment for South Africa (Biza, Kapingura, \& Tsegaye, 2015), India (Chakraborty, 2016; Dash, 2016), China (Wu \& Zhang, 2009), and Pakistan (Hussain et al., 2009). Also, trade openness and output cyclicality have positive on investment for developing economies (Furceri \& Sousa, 2011).

The literature could not however support a single view favouring either complementary or substitutive effect of public investment on private capital formation. Moreover, theoretical foundation, empirical framework, domestic factors and granularity analysis point to dissimilar conclusion. Since, the crowd-out hypothesis of private investment is still inexplicable for Indian economy, we revisit and display annotations of dynamic link between the gross fixed capital formation (GFCF) of public and private sectors with top-down approach - starting with aggregate level and drill down to industry level - controlling macro-economic, monetary and fiscal variables. Primarily the study analyses direct crowd-out effect, interest rate dynamics is captured through credit cost, inflation expectation besides macroeconomic vulnerability and economic cycle. Accordingly, the explicit hypothesis of this study are (a) public investment crowds-out private 
investment at aggregate, sectoral (infrastructure, non-infrastructure, services etc.) and industry level, (b) fiscal deficit crowds-out private investment, and (c) macroeconomic vulnerability and expected inflation dampen private investment. In this sense, the study aims to contribute to the literature by analysing empirically the ambiguous crowding-out hypothesis for India considering comprehensive macro-economic and fiscal variables at aggregate, sectoral and industry level. Such comprehensive consideration of probable investment's determinants are missing in literature for country specific study.

The GFCF is acquisition and creation of assets for their use in medium to long run netted against disposals of produced fixed assets. In Indian context, this study makes probably first use of back series disaggregated (industry level) investment statistics covering financial year 1980-1981 to 2018-2019 with 2011-12 as reference year. The public sector investment rate ${ }^{1}$ was higher than the private sector until early 1990s. But the trend reversed by mid-1990s; private investment crossed over and remains above public investment barring few intermittent years in early 2000s (Figure 1a). However, moderation of investment since 2006-07 is a concern, though the recent broad basing of credit uptick may streamline sectoral investments going forward. Declining of stalled projects, reforms in telecom, power, real estate and synchronised public-private partnerships for infrastructure help investment revival (Raj, Sahoo, \& Shankar, 2018).
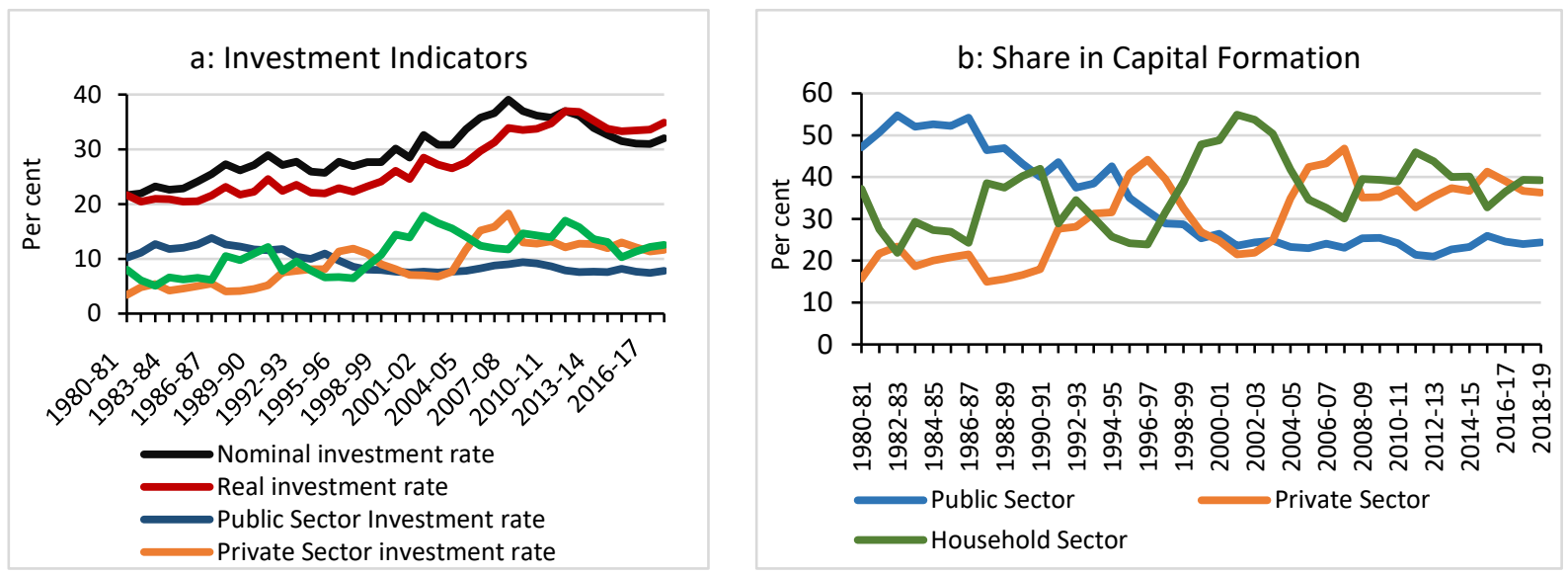

Source: Reserve Bank of India

Figure 1. Investment Dynamics

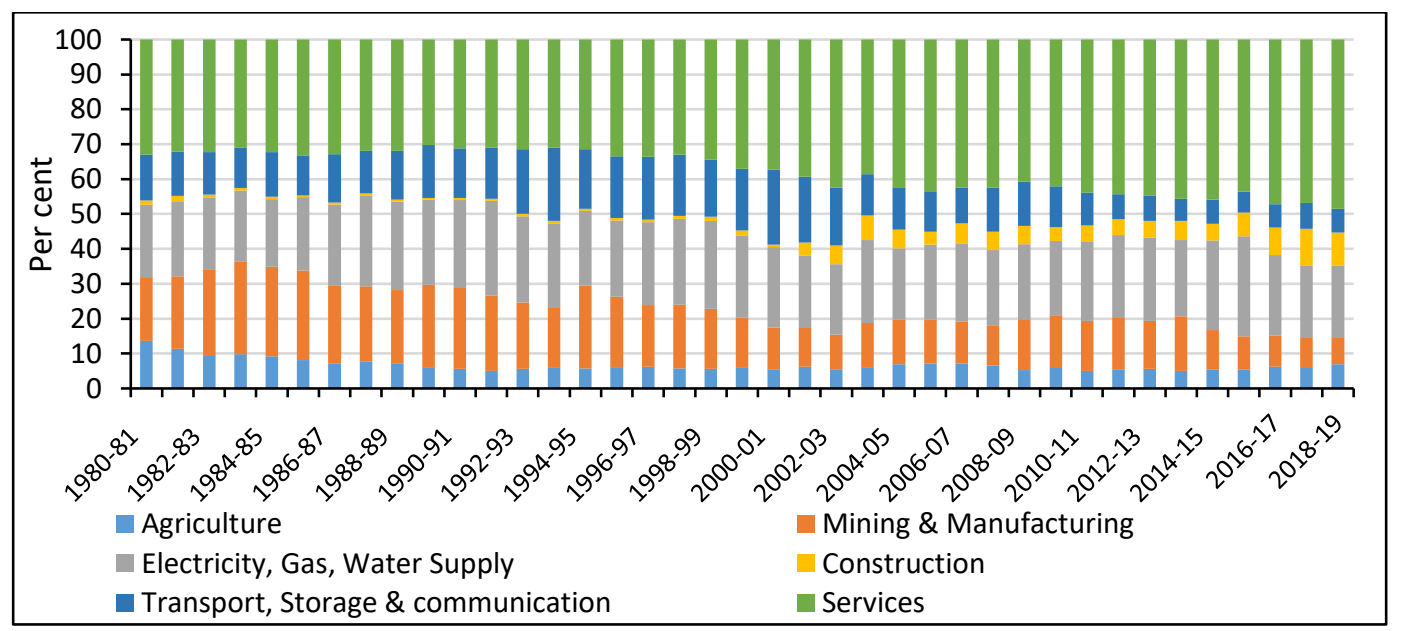

Source: Government of India

Figure 2. Share of Public Sector Investment

\footnotetext{
${ }^{1}$ Public investment includes government investment also. Investment rates are the ratio of GFCF to the gross value addition (GVA).
} 
The investment share of private sector crossed above public sector and remained elevated since 2003-04 (Figure 1b), however, gap between public investment in infrastructure and noninfrastructure has been widening in recent years (Figure 2). The decadal correlation coefficient between public and private investment rate revels that initial substitutive effect (correlation -0.61 during 1990-2000) reverses to complementarity (correlation 0.78 and 0.70 , respectively) during subsequent decades (Table 1). However, for entire study period negative correlation $(-0.65)$ is suggestive of a substitutive relationship. Additionally, volatility of public investment rate (1.9) was about half that of private investment (3.8), points toward unreliable nature of private investment in Indian context.

Table 1. Investment Rate - Stylised Summary

\begin{tabular}{clllllllll}
\hline & \multicolumn{4}{c}{ Private Sector } & \multicolumn{5}{c}{ Public Sector } \\
\hline Years $\$$ & Mean & Max & Min & Std. Dev. & Mean & Max & Min & Std. Dev. & Correlation \\
\hline $1980-81$ to $1989-90$ & 4.6 & 5.5 & 3.4 & 0.7 & 12.1 & 13.8 & 10.2 & 1.0 & $0.72^{* *}$ \\
$1990-91$ to $1999-00$ & 8.8 & 11.9 & 5.2 & 2.0 & 9.7 & 11.8 & 7.7 & 1.5 & $-0.61^{*}$ \\
$2000-01$ to $2009-10$ & 11.5 & 18.3 & 6.8 & 4.2 & 8.3 & 9.4 & 7.5 & 0.8 & $0.78^{* * *}$ \\
$2010-11$ to $2016-17$ & 12.3 & 13.2 & 11.3 & 0.6 & 7.8 & 8.7 & 7.4 & 0.4 & $0.70^{* *}$ \\
$1980-81$ to $2018-19$ & 9.2 & 18.3 & 3.4 & 3.8 & 9.5 & 13.8 & 1.9 & 1.9 & $-0.65^{* * *}$ \\
\hline
\end{tabular}

Notes: $* * *, * *$ and $*$ represents significance at $1 \%, 5 \%$ and $10 \%$ level, respectively.

\$: Financial year of India (April to March)

Whether deficit financing poses capital constraint to private investment is a much-debated issue of macro-economy; more so in developing economy like India considering recent fiscal slippage and dismal investment scenario amidst subsidy support, bank's asset quality deterioration, squeeze of credit flows to non-financial private sector and protracted slowdown. Therefore, examining crowding-out phenomenon is essential for informed policy decision to mitigate potential adverse impact on productive private investment.

\section{Methods}

Following Jorgenson (1967) and Blejer and Khan (1984), the desired capital stock may proportional to the expected output.

$K P v t_{t}^{*}=\propto Y_{t}^{\exp }$

where, $K P v t_{t}^{*}, Y_{t}^{e x p}$ and $\propto$ are desired capital stock by private sector, expected output and a constant, respectively. Further, under partial adjustment mechanism, the actual stock of capital may be adjusted with an adjustment factor to the difference between desired level of capital and actual stock at previous year.

$\Delta K P v t_{t}=\beta\left(K P v t_{t}^{*}-K P v t_{t-1}\right)$

where, $K P v t$ is the actual capital stock, $\Delta K P v t$ net private investment and $\beta(0 \leq \beta \leq 1)$ adjustment coefficient. Theoretically gross private investment is sum of the net private investment and depreciation of the previous capital stock i.e.

$$
\begin{aligned}
& I P v t_{t}=\Delta K P v t_{t}+\delta K P v t_{t-1} \\
& I P v t_{t}=\beta\left(K P v t_{t}^{*}-K P v t_{t-1}\right)+\delta K P v t_{t-1} \\
& I P v t_{t}=[1-(1-\delta) L] K P v t_{t} ; L K P v t_{t}=K P v t_{t-1}
\end{aligned}
$$

Where, $I P v t_{t}$ is gross private investment and $\delta$ is depreciation rate. After little algebraic rearrangement, we get following representation for $I P v t_{t}$.

$$
I P v t_{t}=[1-(1-\delta) L] \beta K P v t_{t}^{*}+(1-\beta) K P v t_{t-1}
$$

By basic assumption of the flexible accelerator model as per equation (1), the private investment may be expressed as: 


$$
I P v t_{t}=\beta \propto[1-(1-\delta) L] Y_{t}^{\exp }+(1-\beta) K P v t_{t-1}
$$

The coefficient $\beta$ captures the private investment response to the gap between desired and actual investment. It varies with factors influencing investment ability of private sector to achieve the desired level of investment.

\section{$\beta=\psi(I P u b, G F D$, WALR, Inf , credit, OG, trade, vulnerability)}

In general, the investment activities depend on credit availability, lending rate and output gap $^{2}$ (Peltonen, Sousa, \& Vansteenkiste, 2012); and expected inflation particularly for inflation targeting economies (Grasso \& Ropele, 2018). The importance of uncertainty in investment as argued by Güney (2020) has been captured through sovereign macroeconomic vulnerability (SMV) - a 3-year rolling standard deviation of cyclic components of vulnerability indicator ${ }^{3}$. Besides, to capture the capital flow investment dynamics, we consider trade openness. The dynamic linear representation of private investment is therefore framed as below.

$$
P R C_{t}=f\left(P R C_{t-i}, P S_{t}, G F D_{t}, W_{A L R}, \text { Credit }_{t}, O G_{t}, T O_{t}, S M V_{t}, \operatorname{Inf}_{t}\right) ; i=1,2, \ldots n
$$

We employ autoregressive distributed lag (ARDL) approach (Pesaran, Sin, \& Smith, 2001) for its implicit advantages over traditional co-integrating framework as it takes care endogeneity of explanatory variables. Both the short and long-run relationship is estimated simultaneously in presence of I(1) variables through the bound test. Further, the Error Correction Model (ECM), derived through a linear transformation, integrates short-run adjustments with long-run equilibrium without losing long-run information.

The investment and macroeconomic statistics are sourced from National Statistical Organization (NSO), Government of India (GoI) and Handbook of Statistics on Indian Economy (HBS), Reserve Bank of India (RBI), respectively. The derived variables vi\%, output gap, sovereign macroeconomic vulnerability and expected inflation are estimated using statistical filters and principal component technique (Appendix). The variables description are given in Annexure Table 1. A priori, we expect a positive or negative coefficient of public investment and output gap in determining private investment. The banks credit flow and trade openness are expected to interact positively; however, lending rate, expected inflation, fiscal deficit and sovereign vulnerability may have a negative coefficient.

\section{Results and Discussion}

We carry out ARDL bound test to examine long-run cointegrating relationship using unrestricted ECM controlling variables stated above. We first check for stationarity of these variables using Augmented Dickey-Fuller (ADF) and Philips-Peron (PP) tests with constant and time trend. Witnessing many reforms in India during the study period, we also report breakpoint ADF test following (Perron, 1989) ${ }^{4}$. The output gap (OG), non-food credit flow (NCF), lending rate (WALR), trade openness (TO) and in few instances public sector capital formation at industry level are stationary only with structural break (Annexure Table 2). We may thus conclude that all variables are either $\mathrm{I}(0)$ or $\mathrm{I}(1)$ with or without breakpoint. The comprehensive representation of ARDL long-run cointegration model, considering all probable variables impacting private investment, is specified below before testing the joint significance of lagged variables using F-test (Wald test).

$$
\begin{aligned}
\Delta \ln P R C_{t}= & \mu+\sum_{i=1}^{n} \beta_{1 i} \Delta \ln P R C_{t-i}+\sum_{i=1}^{n} \beta_{2 i} \Delta \ln P S_{t-i}+ \\
& \sum_{i=1}^{n} \beta_{3 i} \Delta \ln G F D_{t-i}+\sum_{i=1}^{n} \beta_{4 i} \Delta O G_{t-i}+\sum_{i=1}^{n} \beta_{5 i} \Delta \ln N C F_{t-i}+\sum_{i=1}^{n} \beta_{6 i} \Delta W A L R_{t-i}+ \\
& \sum_{i=1}^{n} \beta_{7 i} \Delta \operatorname{ExpINF}_{t-i}+\sum_{i=1}^{n} \beta_{8 i} \Delta T O_{t-i}+\sum_{i=1}^{n} \beta_{9 i} \Delta S M V_{t-i}+\varphi_{1} \ln P R C_{t-1}+
\end{aligned}
$$

\footnotetext{
${ }^{2}$ Output Gap $(\mathrm{OG})=($ Actual Output-Potential Output $) /$ Potential Output *100

${ }^{3}$ Vulnerability Indicator $=($ Fiscal Deficit $/$ GDP + Current Account Deficit/GDP+ GDP deflator $)$

${ }^{4}$ We consider models for data having trend with one-time break determined endogenously assuming break occurs gradually and follows same dynamic path as the innovations (innovation outlier). The tests evaluate the null hypothesis of a unit root process, possibly with a break, against alternative hypothesis of trend stationary with break.
} 


$$
\begin{aligned}
& \varphi_{2} \ln P S_{t-1}+\varphi_{3} G F D_{t-1}+\varphi_{4} O G_{t-1}+\varphi_{5} \ln N C F_{t-1}+\varphi_{6} W A L R_{t-1}+ \\
& \varphi_{7} \operatorname{ExpINF}_{t-1}+\varphi_{8} \text { TO }_{t-1}+\varphi_{9} S M V_{t-1}+\rho D u m m y_{i}+\epsilon_{t}
\end{aligned}
$$

To measure the asymmetric impact on private investment at sectoral level of public investment $\left(P S_{t}\right)$, we segregate public investment in infrastructure, non-infrastructure, core infrastructure and service sector, considering importance of infrastructure investment as it leads to employment driven growth for emerging economies (Nasution \& Imam, 2017). We consider public non-infrastructure investment as investment in mining \& quarrying, manufacturing, trade, hotels \& restaurants, financial services, real estate and business services, public administration, defence and other services (Chakraborty, 2016). Similarly, infrastructure investment includes investment in agriculture (especially irrigation); electricity, gas, water supply; construction; transport, storage and communication. Further, the core-infrastructure excludes agriculture from infrastructure investment as capital formation under irrigation projects is not explicit. We further extend the analysis at industry level of public sector investment. The null hypothesis of no cointegrating relationship is as below:

$H_{0}: \varphi_{j}=0$ for $j=1,2, \ldots \ldots, n$

The F-statistic (Wald test) under the null follows a non-standard distribution in presence of non-stationary variables and thus test statistic is compared with two asymptotic critical values in presence of $\mathrm{I}(0)$ and $\mathrm{I}(1)$ variables to conclude a cointegrating relationship (Pesaran et al., 2001). If computed F-statistic falls outside critical value of $\mathrm{I}(1)$, we may reject the null; if falls within the critical band of $\mathrm{I}(1)$ and $\mathrm{I}(0)$, decision is inconclusive; and outside with reference to $\mathrm{I}(0)$ critical value implies no cointegrating relationship among the covariates. Subsequently, short run ECM representation is estimated as below:

$$
\begin{aligned}
\Delta \ln P R C=\alpha & +\sum_{i=1}^{n} \beta_{1 i} \Delta \ln P R C_{t-i}+\sum_{i=1}^{n} \beta_{2 i} \Delta \ln P S_{t-i}+ \\
& \sum_{i=1}^{n} \beta_{3 i} \Delta \ln G F D_{t-i}+\sum_{i=1}^{n} \beta_{4 i} \Delta O G_{t-i}+\sum_{i=1}^{n} \beta_{5 i} \Delta \ln N C F_{t-i}+\sum_{i=1}^{n} \beta_{6 i} \Delta W A L R_{t-i}+ \\
& \sum_{i=1}^{n} \beta_{7 i} \Delta \operatorname{ExpINF}_{t-i}+\sum_{i=1}^{n} \beta_{8 i} \Delta T O_{t-i}+\sum_{i=1}^{n} \beta_{9 i} \Delta S M V_{t-i}+E C M_{t-1}+ \\
& \rho \text { Dummy }_{i}+\vartheta_{t}
\end{aligned}
$$

\begin{tabular}{|c|c|c|c|c|}
\hline ARDL Models (Lag) & $2,0,0,1,1,2,0,0$ & $2,1,0,1,1,2,0,0$ & $2,2,0,1,1,2,0,0$ & $2,0,0,1,2,2,0,0$ \\
\hline \multicolumn{5}{|c|}{ Dependent Variable: Private Corporate Sector Investment (Ln PRC) } \\
\hline Common Regressors & Ln PS, Ln GF & NCF, WALR, I & & \\
\hline Distinct Regressors & OG, TO & TO, SMV & OG, SMV & SMV, DREF*LPS \\
\hline F-statistic & $10.87 * * *$ & $10.85^{* * *}$ & $12.89 * * *$ & $16.34 * * *$ \\
\hline \multicolumn{5}{|c|}{ Diagnostic Statistics } \\
\hline$F-$ Stat $_{\text {Serial }[2]}$ & $0.7651(0.27)$ & $3.8873(0.11)$ & $4.2554(0.13)$ & $2.6207(0.10)$ \\
\hline$F-$ Stat $_{\text {Arch }[1]}$ & $0.0090(0.92)$ & $1.3395(0.65)$ & $1.9992(0.77)$ & $1.2732(0.29)$ \\
\hline$F-$ Stat $_{\text {Reset }[1]}$ & $1.1671(0.29)$ & $0.5397(0.47)$ & $0.0969(0.76)$ & $0.4402(0.51)$ \\
\hline \multicolumn{5}{|c|}{ Critical Value Bounds for Regressors $(\mathrm{k}=7)$} \\
\hline Significance Level & $10 \%$ & $5 \%$ & $2.50 \%$ & $1 \%$ \\
\hline Lower Bounds $\mathrm{I}(0)$ & 1.92 & 2.17 & 2.43 & 2.73 \\
\hline Upper Bounds I(1) & 2.89 & 3.21 & 3.51 & 3.90 \\
\hline
\end{tabular}

Where, $\Delta$ denotes difference operator, $\beta$ indicates short run multiplier of respective regressors and $E C M_{t-1}$ is lagged error correction term with expected coefficient ranged between $(-1,0)$.

Table 2. ARDL Bounds Test at Aggregate Level of Investment

Notes: ${ }^{* *},{ }^{* *}$ and $*$ denote statistical significance at $1 \%, 5 \%$ and $10 \%$ level, respectively. p-value are reported in parenthesis. Ln denotes natural logarithm. Square brackets represent lag length.

As the computed F- statistic falls in the rejection region, the bound test confirms a cointegrating relationship among covariates (Table 2). The results at aggregate level are presented in Table 3. The long run estimated coefficients of public investment is positive (ranged from 0.78 to 1.14) and statistically significant across the models; indicate a complementarity between private and public investment; in line with the previous studies of Muthu (2017), Bahal et al. (2018) and (Akber et al., 2020) for India. The net credit flow and cost of credit impact positively, imply that private investment in long-run is insensitive to interest rate with adequate credit flow. However, 
expected inflation dampens the private investment. Moreover, deficit coefficient signifies that one per cent increase of fiscal deficit reduces private investment by over half percent. The estimated trade openness coefficient $(-0.03)$ have diminishing effect on the private investment, possibly due to persistency of trade deficit over the years for India economy.

The negative coefficients of inflation expectation and sovereign vulnerability underscore their importance for private sector investment in long-run. Thus, for policy perspective, containing inflation and vulnerability are imperative to buttress private investment. The negative elasticity of output gap, though low indicates the slowdown of private investment when economy is overheated (positive output gap). Thus, optimizing the actual output around the potential may be desirable to attract private investment. Next, we estimate the short-run dynamics with appropriate exogenous dummies for 1990s reform, structural breaks and general election year of India for capturing political uncertainty in election year. The estimated ECM coefficients are negative, statistically significant and bounded by $(-1,0)$ (Table 4$)$. It signify that against the short-term disequilibrium, private investment adjusts in a range of 81 to 89 per cent within a year to restore long-run equilibrium. In short-run, cost of credit and expected inflation dampen private investment, but credit flow has significant positive relationship as expected. The reform dummy is significant and positive, but election dummy doesn't diminish private investment against the conjecture.

Table 3. Long Run Estimates at Aggregate Level

\begin{tabular}{|c|c|c|c|c|}
\hline \multicolumn{5}{|c|}{ Dependent Variable: Private Corporate Investment (Ln PRC) } \\
\hline $\begin{array}{c}\text { ARDL } \\
\text { Model/Variables }\end{array}$ & $2,0,0,1,1,2,0,0$ & $2,1,0,1,1,2,0,0$ & $2,2,0,1,1,2,0,0$ & $2,0,0,1,2,2,0,0$ \\
\hline Ln PS & $0.779^{* * *}(5.799)$ & $0.906^{* * *}(11.557)$ & $1.136^{* * *}(10.013)$ & $1.054 * * *(8.812)$ \\
\hline Ln GFD & $-0.538^{* * *}(-3.741)$ & $-0.518 * * *(-4.95)$ & $-0.556 * * *(-4.32)$ & $-0.562 * * *(-4.522)$ \\
\hline Ln NCF & $0.71 * * *(6.633)$ & $0.554 * * *(7.846)$ & $0.373^{* * *}(8.217)$ & $0.476^{* * *}(7.055)$ \\
\hline WALR & $0.057 *(2.048)$ & $0.05^{* * *}(3.139)$ & $0.056 * *(2.596)$ & $0.084 * * *(3.252)$ \\
\hline EINF & $-0.467 * * *(-5.446)$ & $-0.358 * * *(-5.365)$ & $-0.308 * * *(-4.658)$ & $-0.306 * * *(-4.073)$ \\
\hline OG & $-0.042 *(-1.861)$ & & $0.0070(0.504)$ & \\
\hline TO & $-0.029 * * *(-3.029)$ & $-0.015^{* *}(-2.656)$ & & \\
\hline SMV & & $-0.069 * * *(-3.019)$ & $-0.096 * * *(-3.745)$ & $-0.070 * * *(-3.314)$ \\
\hline DREF*Ln PS & & & & $0.020 * *(2.732)$ \\
\hline $\mathrm{C}$ & $4.603 * *(2.387)$ & $3.351 * *(2.499)$ & $2.045(1.636)$ & $1.771(1.046)$ \\
\hline
\end{tabular}

Table 4. Short Run Estimates at Aggregate Level

\begin{tabular}{|c|c|c|c|c|}
\hline \multicolumn{5}{|c|}{ Dependent Variable: $\Delta$ Private Corporate Investment ( $\Delta$ Ln PRC) } \\
\hline$\Delta$ Ln PRC (-1) & $0.245^{* * *}(3.581)$ & $0.245^{* * *}(3.671)$ & $0.181 * * *(2.92)$ & $0.189 * * *(3.384)$ \\
\hline$\Delta$ Ln PS & & $1.162 * * *(7.936)$ & $1.586^{* * *}(10.142)$ & \\
\hline$\Delta \operatorname{Ln} \operatorname{PS}(-1)$ & & & $0.416^{* *}(2.486)$ & \\
\hline$\triangle \mathrm{Ln} N \mathrm{NCF}$ & $0.253 * * *(7.236)$ & $0.176^{* * *}(5.391)$ & $0.078 * * *(3.127)$ & $0.146^{* * *}(5.106)$ \\
\hline$\Delta$ WALR & $-0.097 * * *(-3.845)$ & $-0.104 * * *(-4.102)$ & $-0.079 * * *(-3.453)$ & $-0.103^{* * *}(-4.791)$ \\
\hline$\Delta$ WALR(-1) & & & & $-0.050 * *(-2.389)$ \\
\hline$\Delta \mathrm{EINF}$ & $-4.088 * * *(-10.161)$ & $-3.421 * * *(-10.089)$ & $-2.574 * * *(-10.336)$ & $-2.658^{* * *}(-11.379)$ \\
\hline$\Delta \mathrm{EINF}(-1)$ & $4.037 * * *(10.051)$ & $3.402 * * *(10.237)$ & $2.531 * * *(10.475)$ & $2.628^{* * *}(11.224)$ \\
\hline DBREAK & $0.072 *(1.853)$ & & $-0.057 *(-1.888)$ & \\
\hline DREF & & $0.250 * * *(8.868)$ & $0.386^{* * *}(11.639)$ & \\
\hline DELECTION & & & $0.097 * * *(4.349)$ & \\
\hline ECM t-1 & $-0.814 * * *(-11.549)$ & $-0.872^{* * *}(-11.613)$ & $-0.864 * * *(-12.944)$ & $-0.894 * * *(-14.162)$ \\
\hline \multicolumn{5}{|c|}{ Diagnostic Statistics } \\
\hline Adjusted $R^{2}$ & 0.76 & 0.83 & 0.88 & 0.83 \\
\hline S.E. of regression & 0.082 & 0.069 & 0.059 & 0.070 \\
\hline SBC & -1.68 & -1.96 & -2.098 & -2.000 \\
\hline DW Statistics & 2.23 & 2.74 & 2.77 & 2.56 \\
\hline F-Statistic & $864.31(000)$ & $1124.4(000)$ & $1235.51(000)$ & $1190.62(000)$ \\
\hline
\end{tabular}



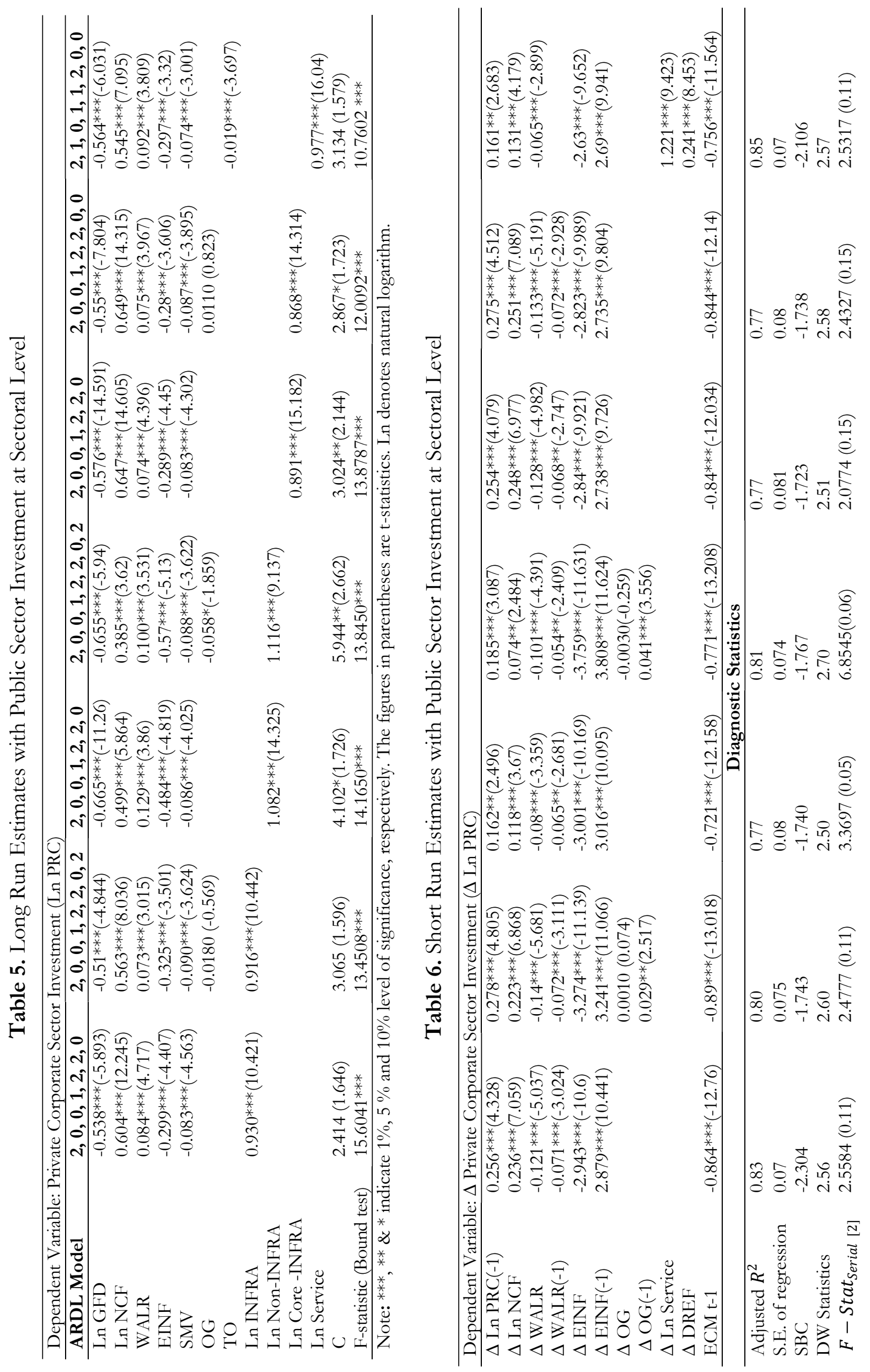
We further analyze the impact of public investment at sectoral level for private investment activities. The ARDL bound tests confirm the existence of a cointegrating relationship among the covariates. The long and short-run coefficients are presented in Table 5 and Table 6 , respectively. The results confirm that (a) fiscal deficit dampens private investment in long-run and more severe when public sector invests in non-infrastructure/service sector, (b) uptick in credit flow promotes private investment in long run, signifies a conducive credit environment for spurring the investment growth, (c) inflation expectation bearings negatively for private investment in long and short-run though lending rate pulls it down in short-run only, (d) sovereign vulnerability squeezes private investment in long run across the sector. Further, public sector investment in infrastructure, non-infrastructure, core-infrastructure and services sector compliment homogeneously to private capital formation. However, trade openness doesn't help to boost private investment in long-run (coefficient: -0.19) indicative of reliance on domestic investment, though 1990s reform helps to spur private investment in short-run (coefficient: 0.24 ) in India.

The crowding-in results of infra and non-infra investment at sectoral level are consistent with empirical evidence of Chakraborty (2016) for India and Kollamparambil and Nicolaou (2011) for South Africa. The result however, contradicts insignificant impact of Muthu (2017) for infra and non-infra sector in India. Further, none of the previous study empirically adjudged crowd-out effect of public investment in service industries against perception of a substitutive effect. This study observes a positive elasticity of public service sector investment and hence supports for private investment. Moreover, the negative impact of fiscal deficit is quantitatively higher when public sector invest in non-infra or service sector as higher government borrowing may push either interest rate up or displace investable resources away from private corporate.

We also analyze whether public sector investment at industry level impacts private investment differently; as literature is scanty at this granularity. The ARDL bound tests confirm the existence of cointegrating relationship. The estimated long-run coefficients of industry wide public investment ( 0.28 to 1.02$)$ signifies complementarity with private sector (Table 7$)$, consistent with aggregate and sectoral crowding-in results. Broadly, results are consistent with Muthu (2017) for most of the core-infrastructure industries for India as against crowd-in effect observed across the industries in this study. Further, the long-run negative bearing due to deficit is more significant with public investment in mining and manufacturing (coefficient -1.14) and insignificant with construction and transport, storage and communication (infrastructure sector). Such negative deficit-investment nexus was observed for most of the emerging economies (Biza et al., 2015; Chakraborty, 2016; Wu \& Zhang, 2009). Credit flow supports investment, but inflation and macroeconomic vulnerability drag it in the long and short-run. The cost of credit also dampens investment prospects in short-run, in-sync with findings at aggregate and sectoral level. The estimated ECM coefficients indicate reversion to long-run stability consistently; adjust 35 to 77 per cent within a year's time (Table 8). However, in short-run, barring public investment in financial services and construction, other industry level investment supports private capital formation. Active investment of corporate sectors in financial and construction industries; and resource constraints probably explain the short-run substitutive effect (instantly and with a year lag, respectively) in these industries.

Robustness checks of the estimated models have been carried out for serial correlation, error homoscedastic structure and modal specification; and reported appropriately. Moreover, CUSUM and CUSUM square plots also confirm the parametric stability at 5 per cent level of significance. 


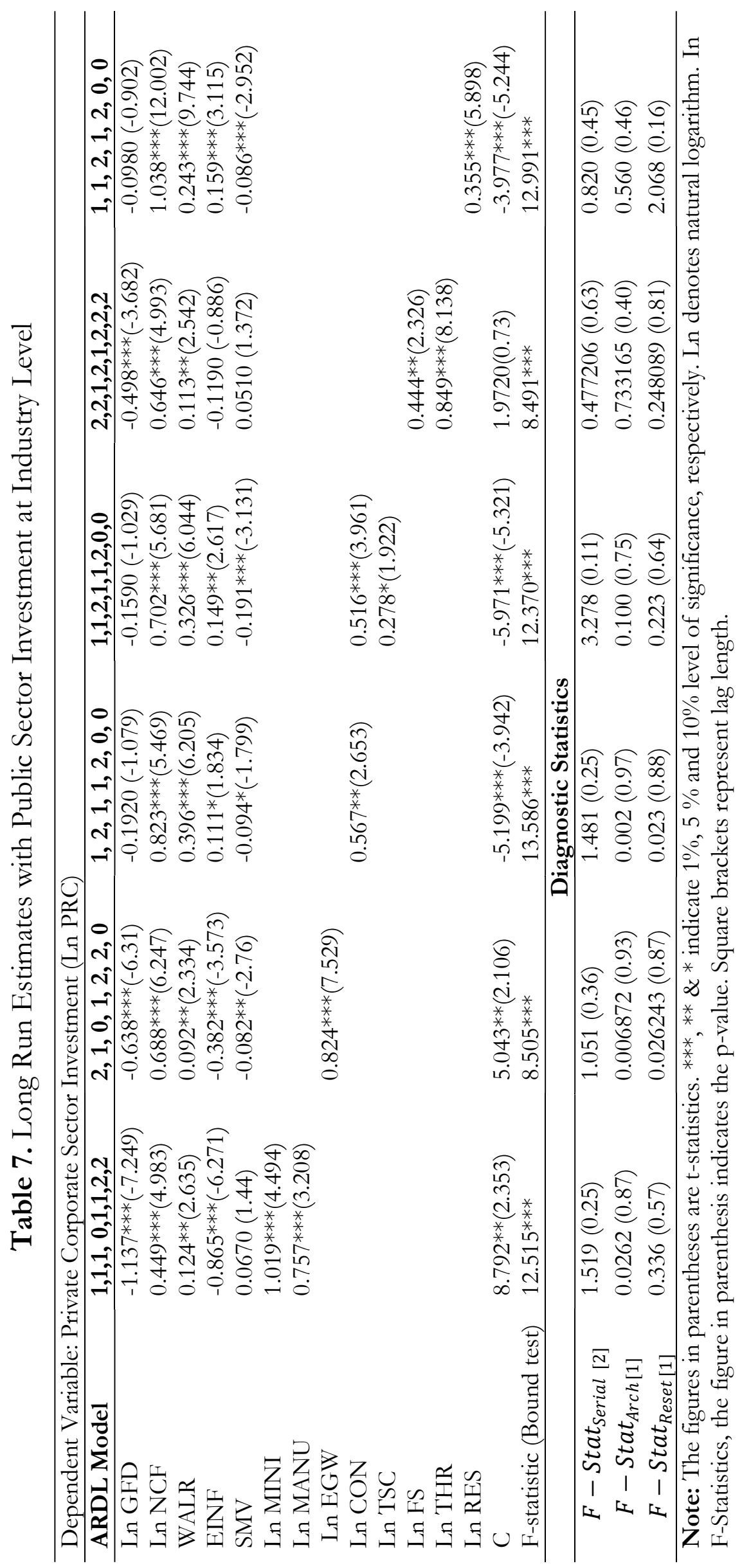




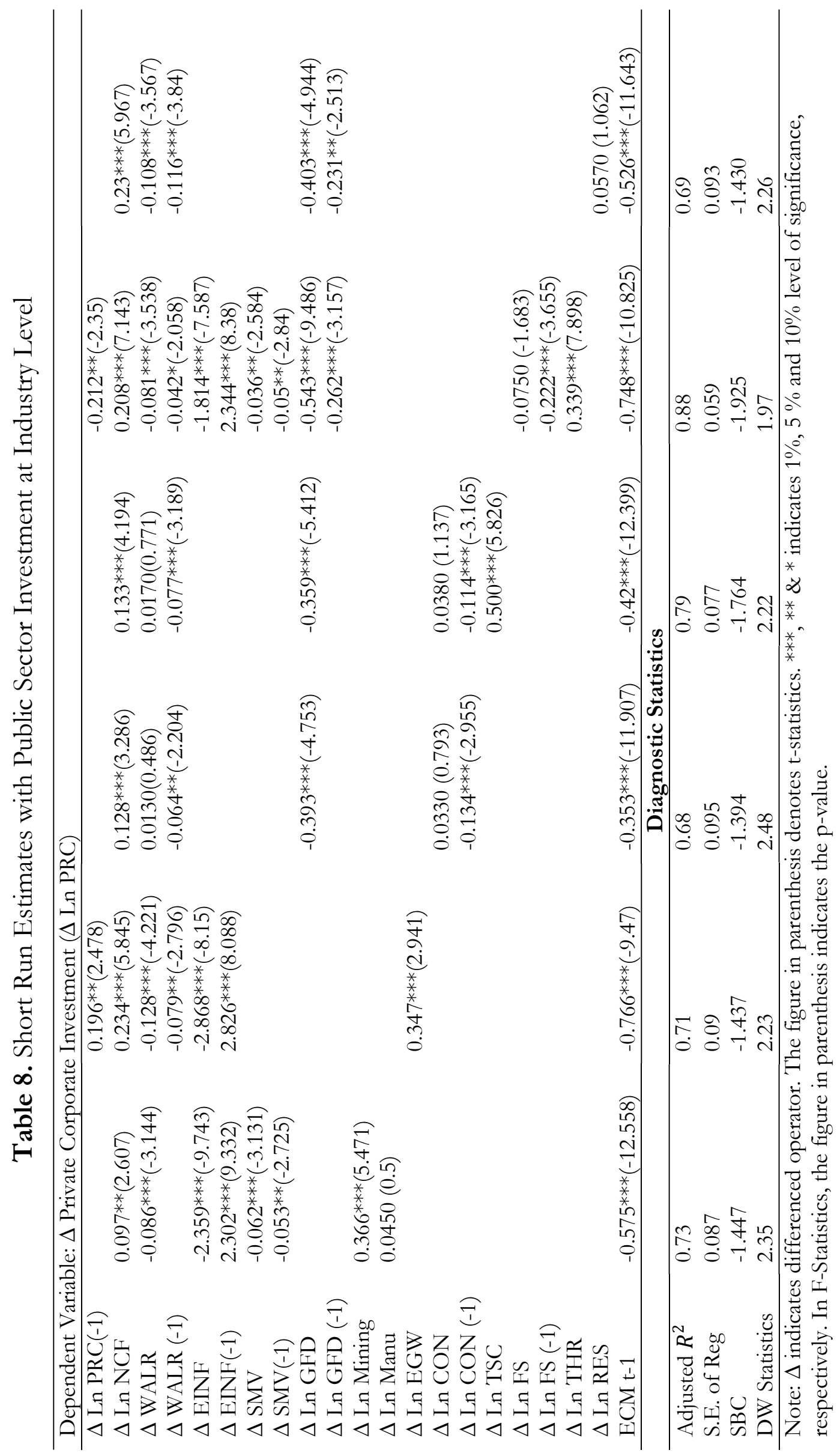




\section{Conclusion}

The study analyses investment crowd-out dynamics between public and private sector in India in a flexible accelerator theoretical setup employing ARDL cointegration estimation method controlling macroeconomic and financial variables including estimated output gap, sovereign vulnerability and inflation expectations using statistical filters and principal components. At the aggregate level, both the long and short-run coefficients support complementarity between private and public investment. Moreover, fiscal deficit, inflation expectation and sovereign vulnerability impact adversely to private capital formation, but credit flow allures. On the other hand, cost of credit appears insensitive in the long-run, though drag on private investment in short-run. Further, public investments at sectoral (infrastructure, non-infrastructure and service sectors) and industry level also complement private investment in long-run; suggestive of a homogeneous reinforcing relationship for India. However, public investment in financial services and construction crowd out private investment contemporaneously and with a year lag, respectively, in short-run. The output gap, trade openness and 1990s reform also influence private investment significantly, more at the sectoral level.

Further, one per cent increase in fiscal deficit may reduce private investment by over 50 basis points in the long-run at aggregate and sectoral level. Moreover, crowding-out bearing of fiscal deficit is significantly higher with public investment in mining and manufacturing and insignificant with infrastructure sub-sectors. Hence, public sector investment in infrastructure may tame adverse impact of expansionary fiscal policy for private investment. The sovereign vulnerability and inflation expectation dampen private investment, but credit flow lures it both in long and short-run. Also, optimizing actual output around the potential through calibrations of policy mix may be apposite to entice sustainable private investment.

Thus, fine-tuning fiscal policy with quality adjustment, containing inflation expectation and macroeconomic vulnerability would create a conducive environment for private corporate investment in India. The directed policy for infrastructure investment with adequate credit flow is desirable to support investment. The study may be extended with quarterly investment statistics at industry level allowing asymmetric and nonlinearity in standard cointegration approach.

\section{Acknowledgments}

The views expressed in the paper are solely of the authors and not of the institutions they belong. Responsibility for any errors or omissions lies solely with the authors. We are thankful to T.S. Shaw, Rama Pal, Anush Kapadia, and other participants of seminar at Indian Institute of Technology Bombay, Mumbai for their valuable comments and suggestions.

\section{References}

Afonso, A., \& St. Aubyn, M. (2010). Public and private investment rates of return: Evidence for industrialized countries. Applied Economics Letters, 17(9), 839-843.

Ahmed, H., \& Miller, S. M. (2000). Crowding-out and crowding-in effects of the components of government expenditure. Contemporary Economic Policy, 18(1), 124-133.

Akber, N., Gupta, M., \& Paltasingh, K. R. (2020). The crowding-in/out debate in Investments in India: Fresh evidence from NARDL application. South Asian Journal of Macroeconomics and Public Finance, 9(2), 167-189.

Anyanwu, A., Gan, C., \& Hu, B. (2018). Government domestic debt, private sector credit, and crowding out effect in oil-dependent countries. In Private Sector Credit, and Crowding Out Effect in Oil-Dependent Countries (July 15, 2018) (Private Sector Credit, and Crowding Out Effect in Oil-Dependent Countries (July 15, 2018)).

Atukeren, E. (2010). Politico-economic determinants of the crowding-in effects of public investments in developing countries. Journal of Money, Investment and Banking, 2010(13), 5573. 
Bahal, G., Raissi, M., \& Tulin, V. (2018). Crowding-out or crowding-in? Public and private investment in India. World Development, 109, 323-333.

Becker, T., \& Mauro, P. (2006). Output drops and the shocks that matter (06/172). IMF Working Paper.

Biza, R. A., Kapingura, F. M., \& Tsegaye, A. (2015). Do budget deficits crowd out private investment? An analysis of the South African economy. International Journal of Economic Policy in Emerging Economies, 8(1), 52-76.

Blejer, M. I., \& Khan, M. S. (1984). Government policy and private investment in developing countries. Staff Papers, 31(2), 379-403. https://doi.org/10.2307/3866797

Buiter, W. H. (1990). Principles of budgetary and financial policy. In MIT Press Classic. The MIT press.

Chakraborty, L. S. (2007). Fiscal deficit, capital formation, and crowding out in India: Evidence from an asymmetric VAR model (No. 518; Working Paper).

Chakraborty, L. S. (2016). Fiscal consolidation, budget deficits and the macro economy. SAGE Publishing India.

Correia, I., Neves, J. C., \& Rebelo, S. (1995). Business cycles in a small open economy. European Economic Review, 39(6), 1089-1113. https://doi.org/10.1016/0014-2921(94)00105-9

Cruz, B. de O., \& Teixeira, J. (1999). The impact of public investment on private investment in Brazil, 1947-1990. In CEPAL Review (No. 67; CEPAL Review).

Dash, P. (2016). The impact of public investment on private investment: Evidence from India. Vikalpa: The Journal for Decision Makers, 41(4), 288-307. https://doi.org/10.1177/0256090916676439

Furceri, D., \& Sousa, R. M. (2011). The impact of government spending on the private sector: Crowding-out versus crowding-in effects. Kyklos, 64(4), 516-533.

Grasso, A., \& Ropele, T. (2018). Firms' inflation expectations and investment plans (No. 1203; Temi Di Discussione (Economic Working Papers)).

Güney, elin Ö. (2020). Macroeconomic uncertainty and investment relationship for Turkey. Economic Journal of Emerging Markets, 12(2), 151-166. https://doi.org/10.20885/ejem.vol12.iss2.art3

Hussain, A., Muhammad, S. D., Akram, K., \& Lal, I. (2009). Effectiveness of government expenditure crowding-in or crowding-out: empirical evidence in case of Pakistan. European Journal of Economics, Finance and Administrative Sciences, 16, 143-149.

Jorgenson, D. (1967). The theory of investment behavior. In National Bureau of Economic Research: Vol. I.

Kollamparambil, U., \& Nicolaou, M. (2011). Nature and association of public and private investment: Public policy implications for South Africa. Journal of Economics and International Finance, 3(2), 98-108.

Mahmoudzadeh, M., Sadeghi, S., \& Sadeghi, S. (2017). Fiscal spending and crowding out effect: A comparison between developed and developing countries. Institutions and Economies, 5(1), 31-40.

Mitra, P. (2006). Has government investment crowded out private investment in India? American Economic Review, 96(2), 337-341. https://doi.org/10.1257/000282806777211621

Muthu, S. (2017). Does public investment crowd-out private investment in India. Journal of Financial Economic Policy, 9(1), 50-69. https://doi.org/10.1108/JFEP-02-2016-0016

Nasution, M. E., \& Imam, W. (2017). Government fiscal policy impact analysis in infrastructure 
sector and education sector to improve public welfare. Economic Journal of Emerging Markets, 9(1), 51-65. https://doi.org/10.20885/ejem.vol9.iss1.art6

Peltonen, T. A., Sousa, R. M., \& Vansteenkiste, I. S. (2012). Investment in emerging market economies. Empirical Economics, 43(1), 97-119. https://doi.org/10.1007/s00181-0110457-0

Perron, P. (1989). The great crash, the oil price shock, and the unit root hypothesis. Econometrica, 57(6), 1361-1401. https://doi.org/10.2307/1913712

Pesaran, M. H., Shin, Y., \& Smith, R. J. (2001). Bounds testing approaches to the analysis of level relationships. Journal of Applied Econometrics, 16(3), 289-326. https://doi.org/10.1002/jae.616

Raj, J., Sahoo, S., \& Shankar, S. (2018). India's investment cycle: An empirical investigation (No. 05; RBI Working Paper Series).

Saeed, N., Hyder, K., Ali, A., \& Ahmad, E. (2006). The impact of public investment on private investment: A disaggregated analysis [with comments]. The Pakistan Development Review, 45(4), 639-663.

Sien, H., \& Kaya, A. (2014). Crowding-out or crowding-in? Analyzing the effects of government spending on private investment in Turkey. Panoeconomicus, 61(6), 631-651.

Serven, L. (1999). Does public capital crowd out private capital? Evidence from India. The World Bank.

Wang, B. (2005). Effects of government expenditure on private investment: Canadian empirical evidence. Empirical Economics, 30(2), 493-504.

Wu, D., \& Zhang, Z. (2009). Effects of government expenditure on private investment-China empirical evidence. 2009 First International Workshop on Education Technology and Computer Science, 3, 86-89. 


\section{Appendix}

Annexure Table 1. Variables Description

\begin{tabular}{|c|c|c|}
\hline Variables & Description & Data Source \\
\hline NCF & Net non-food credit flow from banks & DBIE, RBI \\
\hline EINF & Expected inflation estimated using statistical filter techniques & Authors' estimate \\
\hline GDP Def & GDP Deflator & IMF databank \\
\hline GFD & Gross Fiscal Deficit & MoSPI, GoI and DBIE, RBI \\
\hline INF & Consumer Price Index Inflation & DBIE, RBI \\
\hline OG & Output Gap [ (Actual GVA-Potential GVA)/Potential GVA*100] & MoSPI, GoI and Authors' estimate \\
\hline SMV & $\begin{array}{l}\text { Standard deviation of cyclic component of vulnerability measures with 3-year } \\
\text { rolling window }\end{array}$ & DBIE, RBI and Authors' estimate \\
\hline $\mathrm{TO}$ & Trade Openness (Export and import as per cent of GDP) & DBIE, RBI \\
\hline WALR & Weighted Average Lending Rate & Basic Statistics Return, RBI \\
\hline PS & GFCF in public sector & MoSPI, GoI \\
\hline PRC & GFCF in private corporate sector & MoSPI, GoI \\
\hline HS & GFCF in household sector & MoSPI, GoI \\
\hline AFF & Public sector GFCF in Agriculture, Forestry and Fishing. & MoSPI, GoI \\
\hline MINI & Public sector GFCF in Mining & MoSPI, GoI \\
\hline MANU & Public sector GFCF in Manufacturing & MoSPI, GoI \\
\hline EGW & Public sector GFCF in Electricity, Gas and Water supply. & MoSPI, GoI \\
\hline CONS & Public sector GFCF in Construction & MoSPI, GoI \\
\hline THR & Public sector GFCF in Trade, Repair, hotels \& restaurants & MoSPI, GoI \\
\hline TSC & Public sector GFCF in Transport, storage \& communication & MoSPI, GoI \\
\hline FS & Public sector GFCF in Financial services & MoSPI, GoI \\
\hline RES & Public sector GFCF in Real estate, ownership of dwellings \& business services & MoSPI, GoI \\
\hline PADO & Public sector GFCF in Public administration and defence & MoSPI, GoI \\
\hline INFR & Public sector GFCF in Infrastructure sector & MoSPI, GoI \\
\hline NINFR & Public sector GFCF in non-infrastructure sector & MoSPI, GoI \\
\hline CINFR & Public sector GFCF in core infrastructure sector & MoSPI, GoI \\
\hline Service & Public sector GFCF in Services sector & MoSPI, GoI \\
\hline
\end{tabular}

Annexure Table 2: Unit Root Test

\begin{tabular}{|c|c|c|c|c|c|c|c|}
\hline \multirow{2}{*}{ Variables } & \multicolumn{2}{|c|}{$\begin{array}{c}\text { Augmented Dickey - } \\
\text { Fuller (ADF) }\end{array}$} & \multicolumn{3}{|c|}{ ADF with Structural Break } & \multirow{2}{*}{$\begin{array}{c}\begin{array}{c}\text { Philip- } \\
\text { Perron }\end{array} \\
1 \text { st } \\
\text { Difference }\end{array}$} & \multirow[t]{2}{*}{ Order of Integration } \\
\hline & & $1 \mathrm{st}$ & & $1 \mathrm{st}$ & & & \\
\hline OG & -2.977 & -6.785 & -5.973 & & -2.709 & -11.892 & $\mathrm{I}(1)$ but $\mathrm{I}(0)$ with breakpoint at 2007 \\
\hline Ln GFD & -2.968 & -6.290 & -4.086 & -7.669 & -3.061 & -6.440 & $\mathrm{I}(1)$ \\
\hline Ln NCF & -1.784 & -3.547 & -5.817 & & -1.647 & -3.540 & $\mathrm{I}(1)$ but $\mathrm{I}(0)$ with breakpoint at 2004 \\
\hline WALR & -1.537 & -4.876 & -6.388 & & -1.647 & -4.893 & I(1) but I(0) with breakpoint at 2013 \\
\hline EINF & -1.990 & -3.536 & -3.100 & -13.829 & -2.101 & -3.201 & $\mathrm{I}(1)$ \\
\hline TO & -1.464 & -4.871 & -5.488 & & -1.921 & -4.865 & $\mathrm{I}(1)$ but $\mathrm{I}(0)$ with breakpoint at 2004 \\
\hline SMV & -5.285 & & -10.132 & & -10.132 & & $\mathrm{I}(0)$ \\
\hline Ln PS & -1.328 & -5.333 & -4.264 & -5.595 & -1.259 & -5.321 & $\mathrm{I}(1)$ \\
\hline Ln PRC & -2.377 & -4.758 & -3.618 & -5.104 & -2.114 & -4.772 & $\mathrm{I}(1)$ \\
\hline Ln AFF & 1.335 & -6.459 & -3.276 & -7.466 & 1.335 & -6.470 & $\mathrm{I}(1)$ \\
\hline Ln MINI & -3.022 & -6.384 & -4.111 & -7.103 & -3.022 & -6.492 & $\mathrm{I}(1)$ \\
\hline Ln MANU & -2.414 & -4.950 & -5.366 & & -2.724 & -4.926 & I(1) but I(0) with breakpoint at 1998 \\
\hline Ln EGW & -2.598 & -5.809 & -4.838 & & -2.663 & -5.817 & I(1) but I(0) with breakpoint at 1998 \\
\hline Ln CON & -2.686 & -7.823 & -7.113 & & -2.54 & -7.958 & $\mathrm{I}(1)$ but I(0) with breakpoint at 2000 \\
\hline Ln THR & -2.525 & -6.151 & -4.191 & -7.184 & -2.525 & -7.011 & $\mathrm{I}(1)$ \\
\hline Ln TSC & -2.047 & -5.674 & -3.326 & -6.385 & -2.023 & -5.952 & $\mathrm{I}(1)$ \\
\hline Ln FS & -2.490 & -7.996 & -3.587 & -9.646 & -2.234 & -15.955 & $\mathrm{I}(1)$ \\
\hline Ln RES & -0.637 & -9.079 & -3.817 & -9.036 & -1.78 & -9.036 & $\mathrm{I}(1)$ \\
\hline Ln INFR* & -5.168 & & -6.451 & & -2.706 & -5.938 & $\mathrm{I}(1)$ but $\mathrm{I}(0)$ with breakpoint at 2000 \\
\hline Ln NINFR & -2.578 & -5.436 & -5.090 & & -2.749 & -5.436 & I(1) but I(0) with breakpoint at 1996 \\
\hline Ln CINFR* & -5.102 & & -5.792 & & -2.919 & -6.217 & I(1) but I(0) with breakpoint at 2013 \\
\hline Ln Service & -2.458 & -5.665 & -5.398 & & -2.496 & -6.290 & I(1) but I(0) with breakpoint at 1996 \\
\hline
\end{tabular}

Note: Critical values for ADF unit root test are $-4.22,-3.53$ and -3.20 ; and $-5.35,-4.86$ and -4.61 for $1 \%, 5 \%$ and $10 \%$ level of significance, without and with breakpoint, respectively. *Kwiatkowski-Phillips-Schmidt-Shin (1992) test confirm I(1) without structural break. Ln denotes natural logarithm.

\section{Estimation of Output Gap}

For estimating output gap (OG), literature uses two main variants of statistical filters for extracting the cyclical component of a series. Most of the early literature uses Hodrick-Prescott (HP) filter (Hodrick and Prescott, 1997), though the band-pass (BP) filter proposed by Baxter and King (1999) - $\mathrm{BP}(\mathrm{BK})$ got more prominence lately. Moreover, it's other variants developed by the Christiano 
and Fitzgerald (2003) - BP(CF), using symmetric and non-symmetric weights are also used in literature to tackle the end points problems.

We apply all the statistical filters discussed above to compute the OG by augmenting forecasted output from International Monetary Fund (IMF) to wane the end points concern of filter techniques. We observe large variations in $O G$ estimations using different filters. The $O G$ estimated through $\mathrm{HP}$ and $\mathrm{BP}(\mathrm{BK})$ are aligned, but estimation based on $\mathrm{BP}(\mathrm{CF})$ using symmetric and non-symmetric weights are highly dislocated. We also observe that all four variants of estimated OGs have positive and significant pairwise correlation coefficient. Considering pros and cons of various statistical filters, we construct principal component of output gaps for further use in econometric estimation (Figure A1).

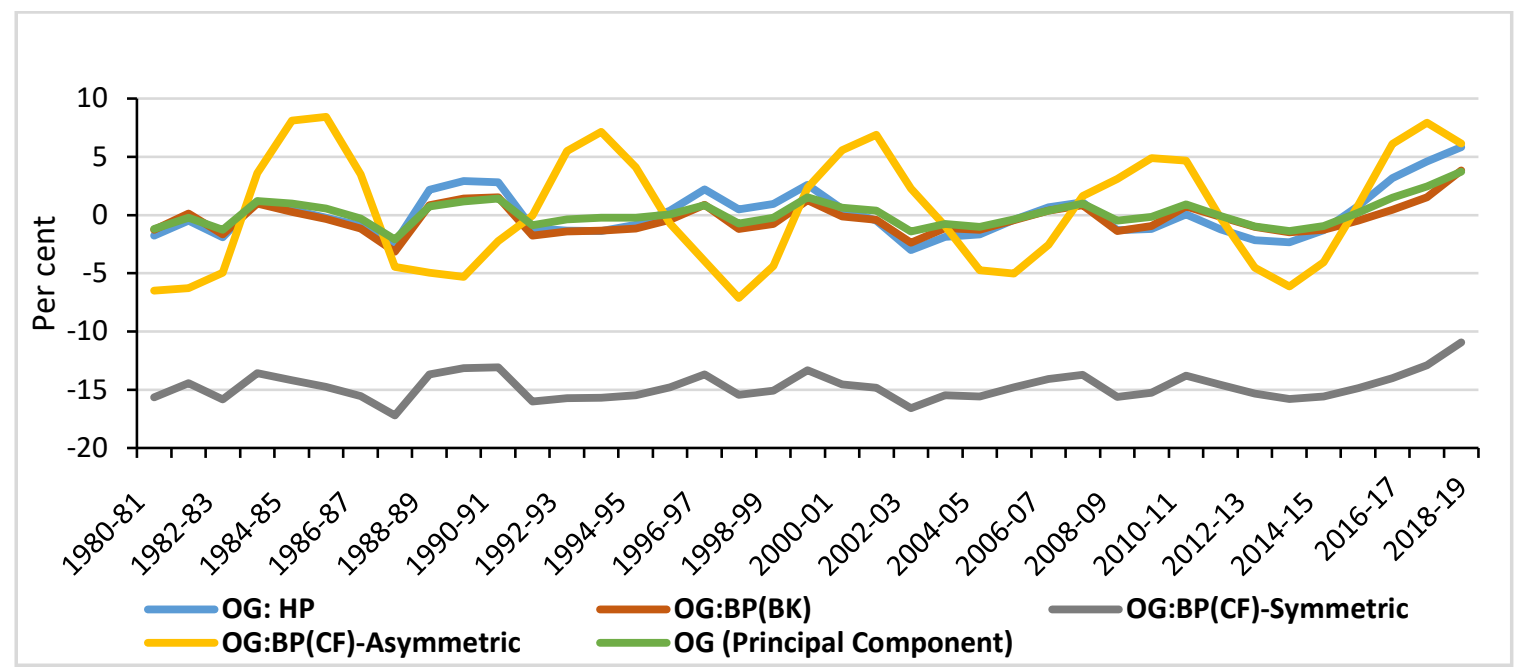

Figure A1. Estimated Output Gap

\section{Estimation of Sovereign Macroeconomic Vulnerability (SMV)}

Many studies examine the impact of macroeconomic vulnerability/volatility on output from investment point of view. The economic volatility evaluates deviation between its present value and equilibrium value and is measured by one of the three popular methods depending upon characteristics of variables and its frequency of availability namely (a) standard deviation of growth rate of a variable (b) standard deviation of the residual of an econometric regression and (c) standard deviation of the cycle isolated by a statistical filter.

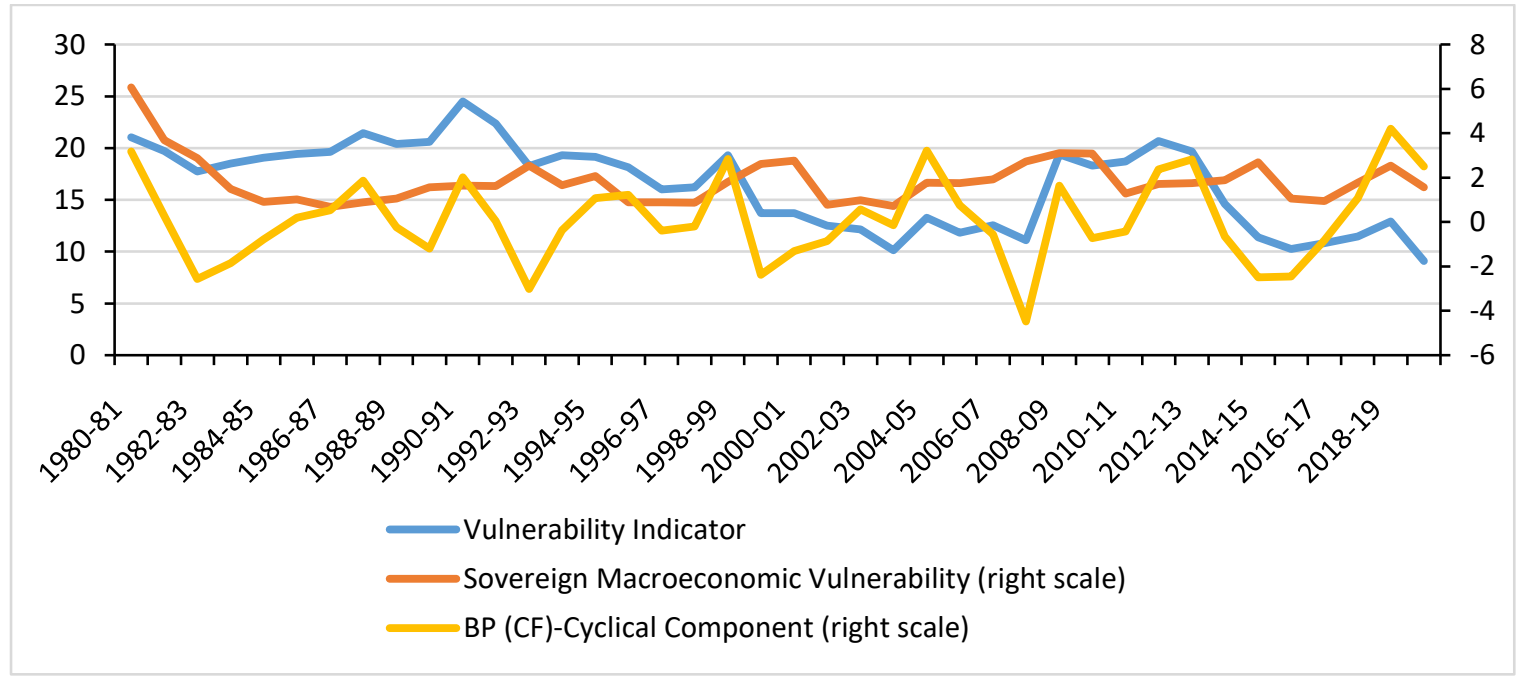

Figure A2. Vulnerability Measures 
Following Becker \& Mauro (2006), we compute standard deviation of estimated cyclical fluctuation of vulnerability indicator as sovereign macroeconomic vulnerability (SMV) for India, contrary to standard deviation of GDP or inflation volatility. The comprehensive measure of annual vulnerability indicator is formed combining deficits and inflation i.e., fiscal and current account deficits as ratio to GDP and GDP deflator (GoI, 2019). We employ BP(CF) with nonsymmetric weight to estimate the cyclical component of the vulnerability indicator and then compute 3-year moving standard deviation considering 3-year duration of investment cycle in India as SMV (Figure A2).

\section{Estimation of Expected Inflation}

Inflation expectation measures the opinion about the future inflation trajectory. Also, the current inflation may partly derive the expectation about inflation and vice-versa. There are three primary ways to track inflation expectations: surveys of household and businesses, survey of professional forecasters, and inflation-linked financial instruments. However, the long series data on either type of surveys are not available for India. Moreover, inflation index bond/capital index bond in India was first issued in 1997, so it is impractical to get market related measure of inflation expectation. Going through the literature, low frequency components estimated using the HP filter has been considered as measure of inflation expectation (Correia, Neves, \& Rebelo, 1995). We apply HP filter on CPI based inflation measure in India to estimate the trend component as measure of inflation expectation, augmenting IMF inflation forecast to tackle filter's end sample issue (Figure A3).

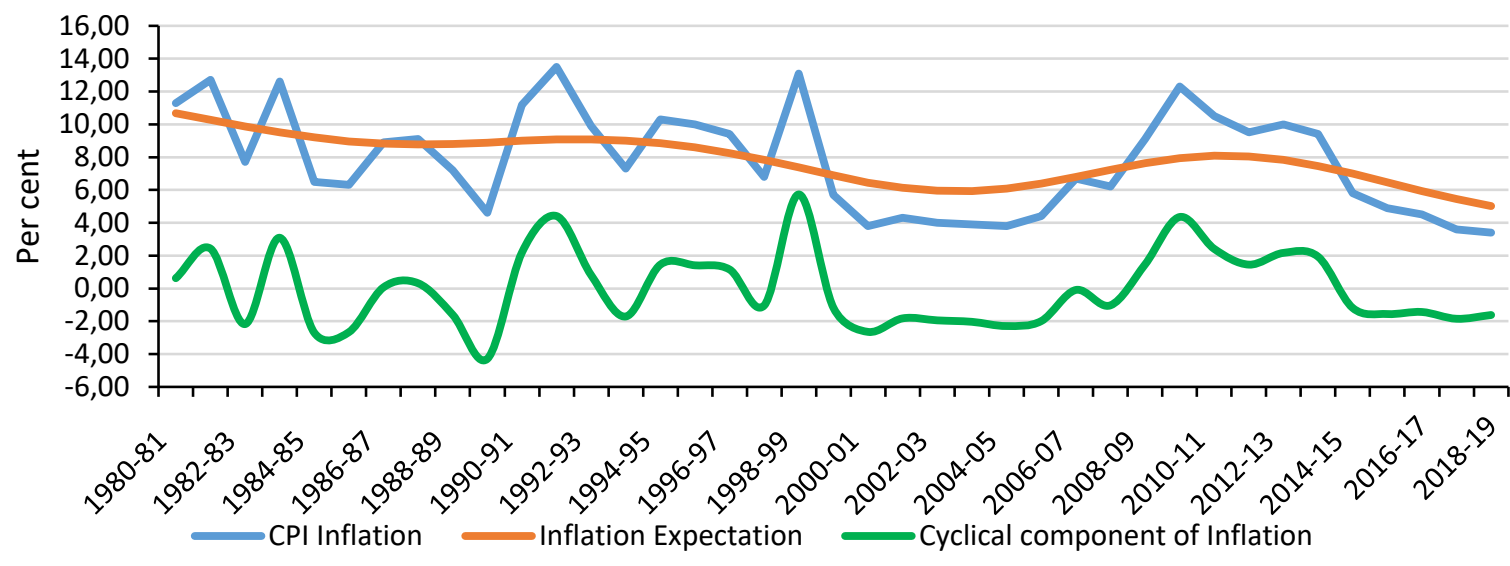

Figure A3. Inflation Decomposition 